\title{
Contemporary Museums of Japan: New Approaches to the Shaping of Architectural and Artistic Image
}

\author{
Nina Konovalova, ${ }^{1, *}$ \\ ${ }^{1}$ Scientific Research Institute of the Theory and History of Architecture and Urban Planning, Branch of the \\ Federal State Budget Institution "Central Scientific-Research and Project Institute of the Construction Ministry \\ of Russia", Moscow, Russia \\ *Corresponding author. Email: phuekirjuko@mail.ru
}

\begin{abstract}
In the late twentieth - early twenty first centuries, one can observe serious changes in the museum architecture; they are connected with dominating new concepts in the museum, exhibition and landscape structure. The ideas of the social and intellectual role of museums are in the process of transformation; new strategies of the museum space are worked out. On the example of Japan, the author makes an attempt to trace main tendencies, dominating in the architecture of contemporary museums.
\end{abstract}

Keywords: Contemporary architecture, Museums of Japan, Concepts of new museums, Museum space, Functionality of contemporary museums.

\section{INTRODUCTION}

The late twentieth and the early twenty first centuries are characterized with a significant increase of the number of museums: modernization and expansion of existing museums and museum complexes, as well as foundation of new ones. The situation can be called a real boom in the museum sphere. For a long time, there has been a continuity of the cultural tradition, which has assumed first the creation of a concept of a certain museum, including an idea of its future collection, and only later, the development of its architectural and artistic image of the museum building on the base of such concept. "Architectural solutions of the museum building were aimed at the maximum disguise against the background of masterpieces of unconditional global importance" [1]. However, at the turn of the twentieth and twenty first centuries, those principles were broken. Recent decades, in various countries, museums were often created without any connection of certain art collections. Japan is a prime example of this phenomenon. Quite often in Japan, a reason for the foundation of

*Fund: This study is based on the research, supported by the Program of Fundamental Research of the Russian Academy of Architecture and Construction Sciences and of the Ministry of Construction, Housing and Utilities of the Russian Federation 2021. a new museum is not a collection, but a desire to show the prosperity of a certain city (or prefecture), or a high level of development of a certain corporation. The shaping of some museum collections is often started only after the working out of certain museum concepts, when the museum building has been already made in project. We mean first of all modern private or small prefectural museums.

Despite the fact that experts note the internationality of contemporary museum architecture as one of its leading characteristics [2], it seems necessary to highlight a number of features of contemporary museums in Japan. Japan is rightfully considered as one of the largest and the most active museum countries, primarily due to a large number of its museums and a high rate of foundation of new ones. Over the past three decades, many new "local" museums were opened in Japan, sometimes, very small, less often - large museums, in the creation of which the principle of the primacy of the architecture of the building over the museum collection is obvious. It is the architecture of new museums that becomes decisive, playing a primary role for both the customer and their visitors. 


\section{ARCHITECTURE OF METAL MESH STRUCTURES AS A PRESENTATION OF WORLD ACHIEVEMENTS IN ARCHITECTURE}

One of the striking examples of new museums created according some advanced architectural experiments is the Fruit Museum in Yamanasi (1996, architect Itsuko Hosegawa). Its design is based on a metal mesh structure, which marks the volume of the building. Itsuko Hosegawa is one of the most famous female architects of Japan. Her works are always innovative, even provocative sometimes. The Yamanasi Fruit Museum is composed of various but interconnected curved fruit-like shapes. Created with the help of 3D modeling, the main building of the museum quite vividly represents a recent trend of museums without any pieces of art. In this case, it includes a tropical greenhouse, an exhibition hall, and craft workshops, but nevertheless the complex is called a museum, not a botanical garden or a greenhouse.

The experimental component of the project continues a tradition of using metal mesh structures, which were regarded in Japan as an advanced global experience as early as a half of a century ago. Suffice to recall the tower of the port of Kobe - one of the most striking symbols of this city. When Nikken Sekkei received an order to build a tower in Kobe, the company carefully studied global experience in the field of construction of high structures with increased stability; they chose the invention by V.G. Shukhov. In 1963, they started to construct a hyperboloid mesh tower in the port of Kobe, corresponding to the tower by Shukhov created for the All-Russian Exhibition 1896 in Nizhny Novgorod. Thus, Nikken Sekkei shaped its own project on the base of the structure, which had received high estimation by specialists as the most promising achievement in the world engineering.

In the creative search of modern architects, mesh structures have kept their relevance till these days; they are considered as one of the most advanced idea in the world. Near the tower of the port of Kobe, in the centre of the park, there is the largest Maritime Museum in the world (architectural bureau: Harbor Maintenance Group). It is crowned with white steel mesh structures, reminding sails full of wind. The museum was founded in 1987 , by the $120^{\text {th }}$ anniversary of the opening of the port of Kobe. Its most important task is to show - with architectural and artistic means as well - the significance of the port of Kobe for the Japanese history, because, for a long time, it had been a link between the country and the outside world.

\section{NEW FUNCTIONS: MUSEUMS NOT FOR COLLECTIONS BUT FOR REFLECTIONS}

Contemporary Japanese architects pay increased attention to new museums, trying to comprehend and explain their changing role. Arata Isozaki argues that a new generation has matured that is abandoning the traditional, generally accepted concept of the museum, realizing a demand to provide specially designed spaces and environments for newly created works of art and installations [3]. In accordance with his ideas, the architect created the Museum of Contemporary Art in Nagi (Nagi MoCA, 1994). Due to the fact that the small town of Nagi has never posessed a significant art collection, Isozaki created his project as a self-sufficient work of architecture, a symbolic structure harmoniously tuned with local traditions and, of course, with the surrounding landscape. And, at that time, it was not even quite clear what exactly would be exhibited in that museum. As a result, the content and artistic part of the project has been developed. The museum housed the works by Isozaki's wife, A. Miyawaki, as well as her colleagues, artists S. Arakawa and K. Okazaki. The significance and attractiveness of this museum for visitors, of course, on a par with the art collection, is formed by the architecture, well-designed space with shaded areas inviting visitors to reflect, to immerse in themselves.

A symbolic form was worked out by architect Toyo Ito, when designing the Suwa Lake Museum in Nagano (1993). There was a very long and narrow site for construction; its outlines became the basis for the plan of the new museum. Ito embodied the image of an inverted boat in the architectural and artistic form of his new building. The image was created so clearly that it was "read" at a glance. Besides, T. Ito - like many representatives of his generation - is in the active search for new ways of form-shaping in architecture, in particular, using computer modeling. "Structural elements and utility fixtures are incorporated into the walls to avoid any protuberances. Both the aluminum panels are the ceiling boards are independent of the body of the structure, covering the gentle curve of the building like a second skin", the architect commented [4]. 
The volume so complicated in its curvature could be created with the $3 \mathrm{D}$ modeling only. It gives a completely new level of the freedom of action, and, consequently, new forms of creative expression. Today, architecture is intensely penetrating into the field of sculpture. Dutch architect Rem Koolhaas emphasizes the properties of building made by Ito their ability to 'absorb' light and to interact with the environment. "While others try to embody the aesthetics of dissolution, Ito effortlessly dissolves and still controls the flow of events" [5]. Ito himself points out that nowadays mechanistic forms have ceased to dominate, they are replaced with the information flow leading in modern society. New images are more likely not the forms but the volumes, in which invisible processes take place. Not the creation of the shapes itself, but the image of space that makes this creation of forms possible becomes more essential [6].

In the Hyogo Prefecture, to preserve the memory of the forests destroyed during the WWII, the Forest Museum was built (1993-94, architect T. Ando). The museum was to become the architectural emblem of the prefecture, symbolically creating its image and conveying its meaning. From the geometric point of view, the building of the Forest Museum in the Hyogo Prefecture is quite simple - a truncated cone with a diameter of $46 \mathrm{~m}$ is installed on the top of the hill. It is clearly bisected from the inside by a pedestrian bridge leading visitors to the forest, to the guest house. The bridge is also a wonderful observation deck. The entire museum building is constructed of wood combined with a steel frame and reinforced concrete. The interior space is organized in a very interesting way. The sloping floor encourages visitors to move down a spiral path that echoes the interior of the hall. The only element appealing to the image of the forest is the 16-meter cedar columns. The theme of contact with nature arises from the cult atmosphere inside the building, which is formed due to the monumentality, which is conceptual for the architect.

The museum space created by Ando does not seem to be intended for exhibits at all. At least, it does not need them. The architect created not exhibition halls but rather a space for reflection. Thanks to its architecture, the Forest Museum has become a self-sufficient object. Visitors strive for it because of their desire to be involved in this space, which captures and bewitches, affects thoughts and feelings, and leaves no one indifferent.

\section{INFORMATION COMPONENT OF CONTEMPORARY MUSEUMS}

In the process of the creation of a museum, an important role is played by its informational component. The completeness of documentation of a certain historical epoch, or the full scale of a collection of pieces of art, or its uniqueness is considered as one of the leading characteristics shaping the informational interest of a visitor to a certain museum. The highlighted trend of the creation of new museums, possessing features not inherent in them before, presupposes the assignment of the information functions to architecture, often to the detriment of the exhibition.

When developing the concept of the K-Museum (1996, architect Makoto Sei Watanabe), the architect set himself a task to create a direct model of a city, emphasizing the high-quality urban life. In the museum image, Makoto Sei Watanabe tried to explain the infrastructure of a modern city, its information flows - in a word, a complex network of functions necessary for its very existence. The museum architecture was designed as a symbol of the modern city. The most important aspect of its perception was the need to emphasize the constant transformation of the urban space, the eternal movement of the city and its pulsating life. All these were to be expressed with the means of architecture.

To create the desired effect, the architect calculated the minimum support required for the building. And he achieved that result. Observing the construction, one gets an impression that its author has captured a short moment of peace in the process of transition from one mode (or state) to another one. The transition is permanent and inevitable. The architect himself called that moment a 'Dash' [7]. Just that moment became the key in the perception of the entire work, because and extrapolation of such situation to the city shows the moment of movement reviving modern metropolis and filling it with life.

A complex relief was artificially built around the museum; it is characterized with serious differences in height. It also became a symbol of a dialogue - a dialogue of essentially immovable architecture with a constantly changing city. The KMuseum consists of various (in materials and geometric shapes) parts; together they form a certain entity as an image of the city, where various architectural styles, differently oriented social 
spaces and so on coexist. And only as a whole they shape a living organism called "city". Thus, the KMuseum was supposed to reflect in a symbolic form the dynamism of the urban development and one of its main characteristics - its diversity, in which a combination of simple components gives rise to a complicated entity. Also noteworthy are a significant number of mirror surfaces on the museum façade. They are located on different sides of the building, under various angles, enhancing that specific discordant and multi-format dialogue between architecture and modern city.

The work by Makoto Sei Watanabe confirms the general trend formed in the creation of Japanese museums, the architectural image of which may provide comprehensive information about their purposes and main ideas. The K-Museum is one of the brightest examples of a museum that allows us to understand its main concept on the base of analysis of its architecture - not its collection.

\section{MUSEUM COMPLEX AS AN ART OBJECT}

The apotheosis of the museum space, capable to influence not only at the emotions and feelings of people but to attract them with the conditions for calming, concentration, and reflections, is the Naosima Contemporary Art Museum (architect T. Ando). It efficiently combines an innovative concept and outstanding architecture. Naosima gets the reputation of the 'island of art'. The museum complex attracts tourists from all over Japan, as well as from abroad. Its quiet, measured rhythm of life and a unique landscape have a soothing and refreshing effect on people tired of the hectic pace of metropolis.

The museum is located on a high promontory of the island and includes a whole complex of buildings - exhibition areas, a conference hall, a restaurant, and a hotel. Ando decided to create a kind of performance, which would be built of the constant transformation of the museum complex, its dynamic development on time and space. The architect planned to add one new building per year. New constructions appear in the complex up now.

All its buildings are perfectly inscribed in the hilly landscape, harmoniously completing it with the stepped forms. The measured composition is stretched out towards the sea, to provide the best panoramic views. According the architect's idea, the natural environment and geometry are to merge together. Walls of wild stone, terraces and open areas are distributed over the territory so smart, that they do not come in conflict with natural forms.

On the base of the peculiarities of that certain natural landscape, Ando built a complex striking with its ability to seem "invisible" in the environment; in fact, it is a traditional practice of Japanese culture. Numerous gardens - dry and with water - adorn the already beautiful museum grounds. It is impossible to see the whole complex from any point, because almost all buildings are set deep in the earth. From different points, one can observe just a part of the museum space.

The central artistic element of the museum complex is an open-air oval hall on the top of a hill, called the 'Pond of Reflections'. An elliptical open roof section is located over the pool, which is illuminated with the natural daylight only. Falling into the building, direct sun beams cannot fill the interior evenly and brightly lighted, they reflect in the mirror-like water surface, and return to the outside. The interior is filled with the play of light and shadow on the glare of water. There are six guest rooms around the pool, because this part of the museum complex is connected with the hotel. Each room of the hotel gives a wonderful sea view.

An interesting conceptual and architectural find was a building of the museum complex buried underground, designed to house paintings by Claude Monet and American artists James Turrell and Walter de Maria. Ando created a structure literally completely underground. Walking around the island, it is even difficult to define it as a building. Even inside the museum a visitor will not leave the feeling that he is walking in nature. The architect created his design, working on the contrast of man-made forms and shapes born by nature. The strict angles of the building, the interior space, the play of light and shadow - all these should prepare visitors for the meeting with the three famous masterpieces of the museum. The exit from the halls passes through a cafe with a magnificent view of the Seto Inland Sea. The lighting of the museum, its atmosphere and even, it seems that the space itself changes with the season and weather conditions. Thus, the entire architectural and artistic image of the museum is also a kind of the 'work of art'. In order to show the picture by Claude Monet as beautifully as possible, only natural light is needed. It is organized in a special way. It was decided not to use direct sunlight, only reflections emanating from the entire hall. A visitor is not to understand where the light is coming from. Therefore, the entire space of the exhibition hall 
was made perfectly white. Both the frames of the paintings and the floor of the exhibition hall were lined with white marble mosaics. The walls of the hall are covered with the whitest plaster, which was used in the Middle Ages for the external covering of the walls of Samurai castles.

The Naosima Contemporary Art Museum on the island is a harmonious combination of architecture, sculpture, and painting with the natural environment; it is not only an object of admiration or criticism, but it serves a kind of catalyst for the re-evaluation one's own worldview.

\section{CONCLUSION}

Museums as they are, undoubtedly, provide contemporary architects with ample opportunities for self-expression. But nowadays, in Japan, as well as throughout the world, there is a tendency to expand the concept of "museum". We can say, that now a space specially designed to demonstrate any specific object, collection, phenomenon, or even an idea, something intangible, can be by right considered as a museum.

In Japan, such structures, difficult for definition in their purpose, appear and, sometimes, they offer nothing to a visitor, if we speak about a museum exhibition, they only push for reflection, contemplation, and inner discoveries.

A large number of the new contemporary museums of Japan do not collections at all. In the urban space, such museum constructions are the art objects themselves. Their architecture often comes to the fore, which is often the only one. Their architectural and artistic image often becomes selfsufficient, trying to convey to a visitor not only some information or idea, but also to inspire him or her to think, to look inside him- or herself.

\section{AUTHORS' CONTRIBUTIONS}

This paper is independently completed by Nina Konovalova.

\section{REFERENCES}

[1] P.Z. Goldin, Museum Architecture: a Look into the History (by A. Marotta's "Contemporary Museums") [Muzeinaia arkhitektura: vzgliad na istoriiu (po materialam raboty A. Mariotty "Sovremennye muzei")], Contemporary World's Architecture
(Sovremennaya arkhitektura mira), 4 (2014) 341 [in Russian].

[2] Museums in the 21st century. Concepts, projects, buildings. By Suzanne Greub (Ed.). Prestel, 2008.

[3] Interview with A. Isodzaki (Interv'iu s A. Isodzaki), Architect. 21th century (Zodchii. 21 vek), 3, (1992) 92. [in Russian].

[4] P. Jodidio. New Forms. Architecture in the 1990s. Tashen, 1997, p. 42.

[5] From the speech by Rem Koolhaas at the 14th architectural biennale in Venice, in 2014.

[6] N.B. Solomon. Architecture: Celebrating the Past, Designing the Future. New York, 2008, p. 180 .

[7] Makoto Sei Watanabe. Conceiving the City. L'Arca, 1998, p. 21. 